\title{
Observation of polar bear (Ursus maritimus) feeding on Sval- bard reindeer (Rangifer tarandus platyrhyncus) - exceptional behaviour or upcoming trend?
}

\author{
Jan Kavan ${ }^{1,2}$ \\ ${ }^{1}$ Polar-Geo-Lab, Department of Geography, Faculty of Science, Masaryk University, \\ Kotlářská 2, CZ-611 37, Brno, Czech Republic \\ ${ }^{2}$ The University Centre in Svalbard, PO Box 156, N-9171 Longyearbyen, Norway
}

\begin{abstract}
A polar bear (Ursus maritimus) was observed feeding on Svalbard reindeer (Rangifer tarandus platyrhyncus) on September $3^{\text {rd }} 2018$ near Skansbukta, central Svalbard. A welldeveloped male was observed to rest nearby and feed on fresh reindeer carcass. Polar bear hunting a reindeer is rather an exceptional behaviour at present, but could become more frequent with drastic decline of sea ice and thus loss of traditional hunting areas with presence of seals - the usual prey.
\end{abstract}

Key words: polar bear, feeding behaviour, reindeer, climate change

DOI: $10.5817 / \mathrm{CPR} 2018-2-20$

\section{Introduction}

Polar bears in Svalbard are usually feeding on the most common species of seal ringed seal (Pusa hispida) and bearded seal (Erignathus barbatus) and to a lesser extent harp seal (Pusa groenlandica) (Derocher et al. 2002, Iversen et al. 2013). Apart their favourite prey, they are also feeding in bird colonies (Stempniewicz et al. 2014) or on carcasses of whales (Derocher et al. 2002, authors' observations). Three cases of intraspecific killing have been reported from Canada in 2004, probably due to nutritional stress related to prolonged ice-free season (Amstrup et al. 2006). The usual habitat for polar bear is the edge of the sea ice especially during winter months but also during the year to hunt for seals or travel between mating, breeding and feeding sites. Some of the polar bears stay on land during summer partly due to rapid decline of sea ice being not able to follow it, partly on purpose especially females searching for maternity denning areas located usually on land (Wiig et al. 2008). Freitas et al. (2012) recorded polar bears with GPS collars on land in $24.6 \%$ of readings. The present population of polar bear in Barents Sea (mostly on and around Svalbard) is estimated up to approximately 3600 individuals (Aars et

Received October 15, 2018, accepted December 18, 2018.

*Corresponding author: J. Kavan <jan.kavan.cb@gmail.com>

Acknowledgements: The study was done thanks to the Arctic Field Grant project "Glacier mass balance - central Svalbard" (RiS ID 10903) funded by The Research Council of Norway and carried out with logistic support of UNIS. The research was also financially supported by the project LM2015078 and project of Masaryk University MUNI/A/1251/2017. Thanks to Dorota Kidawa for comments and suggestions that helped to improve the manuscript. 
al. 2017). The population was under a high anthropogenic pressure during the first half of $20^{\text {th }}$ century due to intensive hunting, which ended in 1973 with the complete ban on hunting (The Agreement on the Conservation of Polar Bears). Since that time the population is growing fast and likely doubled in last 40 years. It is however not clear whether it has already reached the carrying capacity limit and pre-hunting ban number. Aars et al. (2009) stated that this limit hasn't been yet achieved as the population had to be more numerous to sustain an average annual take of about 300 bears over a century in the beginning of the $20^{\text {th }}$ century.

Polar bear hunting of reindeer was long time considered as improbable, however evidence of such behaviour is increasing in recent years. By 1925 Svalbard reindeer had almost gone extinct because of overhunting in the late nineteenth and early twentieth centuries (Tyler 1987). Now the population is increasing (e.g. Derocher 2005). Iversen et al. (2013) identified that Svalbard reindeer occurred in $9.2 \%$ of the polar bear excrements, indicating that this species may play a more important role than previously reported. Derocher et al. (2000) reported 7 cases of polar bear actively chasing reindeer between 1983 and 1999 in Svalbard. The same authors found only a single report of similar behaviour in past - from Greenland reported in Pedersen (1945). Brook et Richardson (2002) observed attempts to hunt a caribou in Hudson Bay on July $16^{\text {th }} 1998$. Recent reported observation comes from Stempniewicz et al. (2014), where a pursuit of a reindeer by polar bear was documented from Magdalenefjorden, northwest Svalbard from July 2011. Tartu et al. (2016) observed a polar bear female with reindeer hair between the teeth from Edgeøya in September 2013, however an active hunt was not proved in this case.

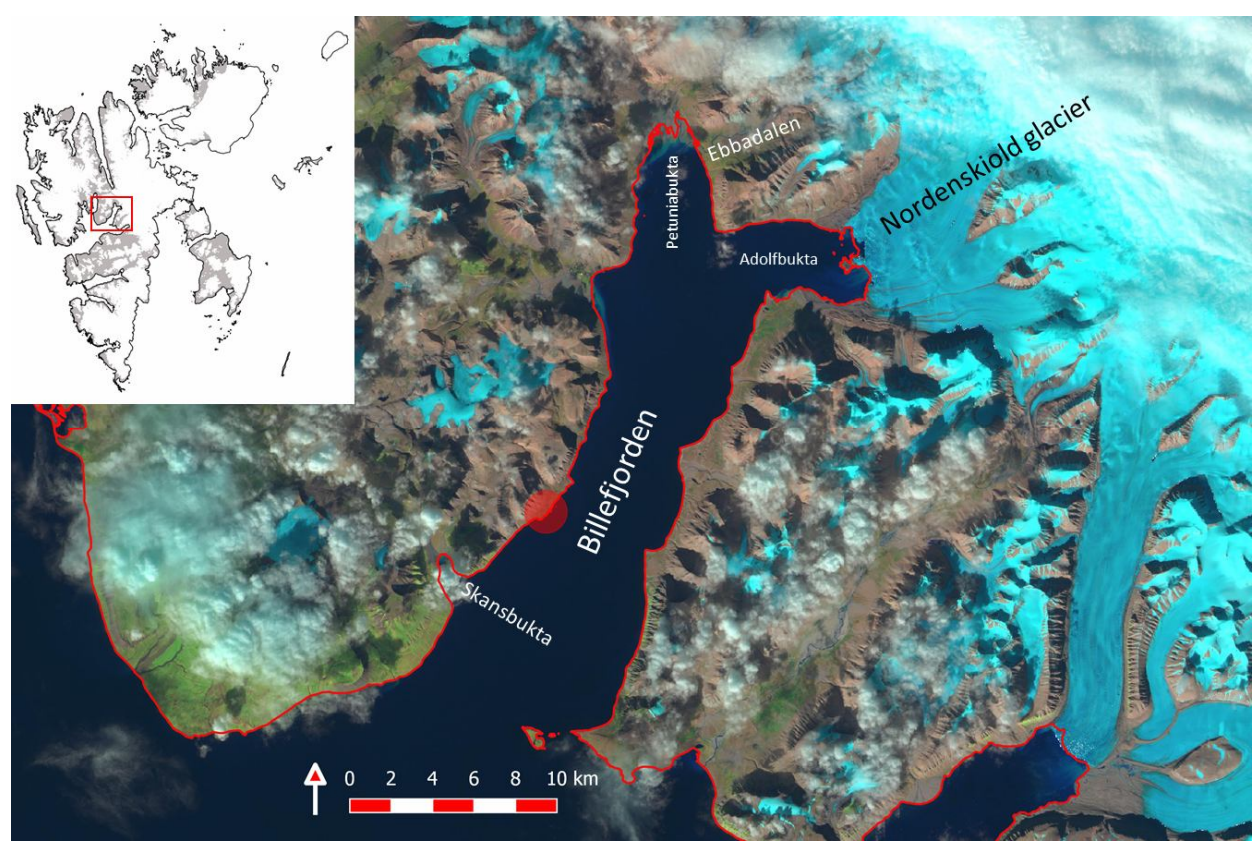

Fig. 1. Location of the observation site (red circle) and its neighbourhood; background picture is taken from Landsat (August 20 ${ }^{\text {th }} 2018$ ) (modified from USGS 2018 [2]), position of the study area within the Svalbard archipelago is marked with red rectangle in the schematic map of Svalbard. 


\section{Observation}

Mature, well-developed and apparently well-fed male was observed on September $3^{\text {rd }} 2018$ near sea shore north off Skansbukta $\left(78.55133^{\circ} \mathrm{N}, 16.24618^{\circ} \mathrm{E}-\right.$ Fig. 1$)$ feeding on reindeer (Fig. 2). The male was of rather big size when comparing to other photographs where a cabin was used as a scale. The bear was resting approximately 30 meters from the shore line, reindeer car- cass was some 20 meters away in a small valley shaped depression. The killed reindeer was on a first sight a mature male, rather well-developed according to its size and antlers. However, the hunt itself was not observed, thus any conclusions on actual health state of the reindeer (e.g. injuries) are not possible to be made.

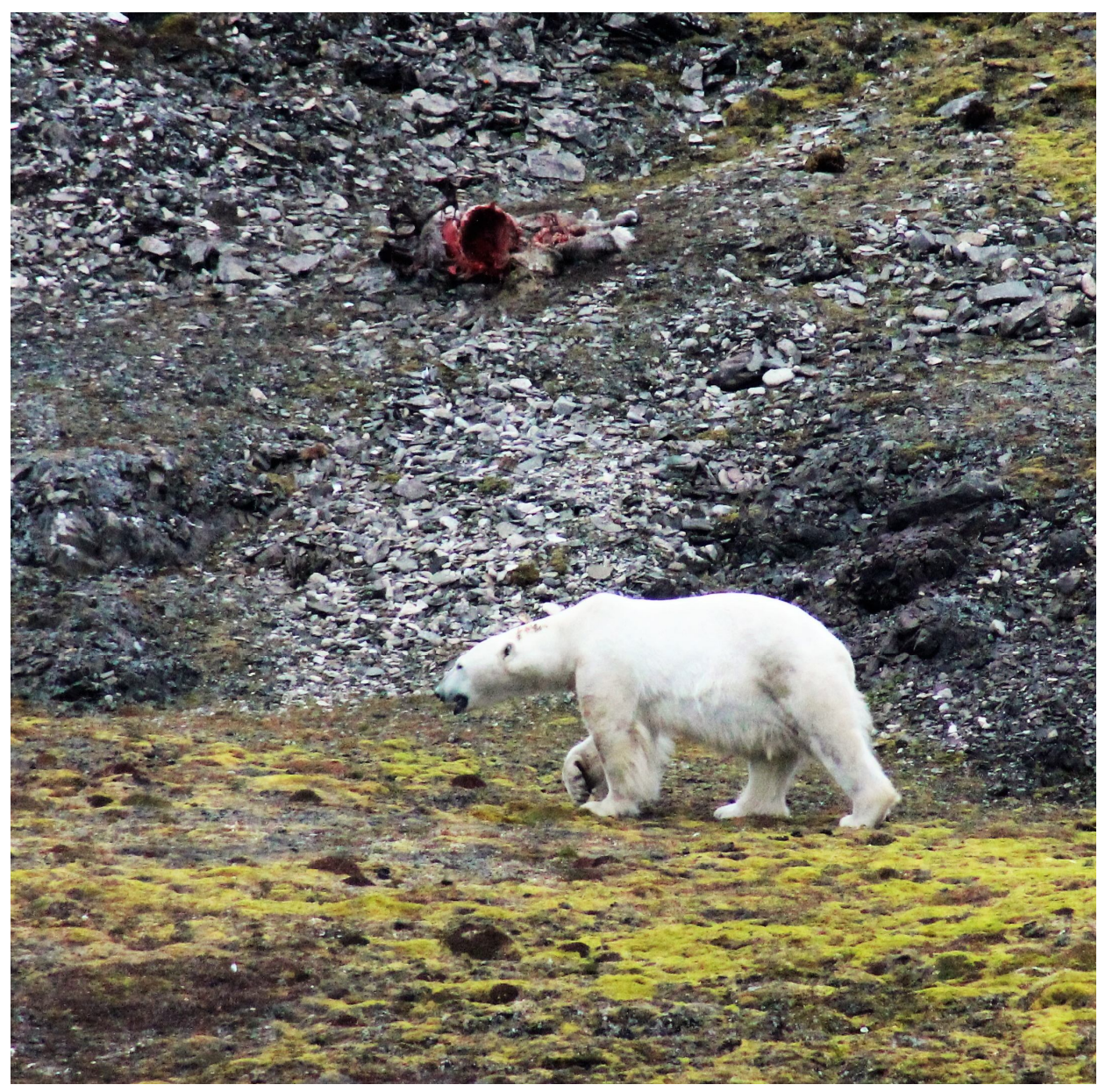

Fig. 2. Polar bear with its prey on September $3^{\text {rd }} 2018$ at 18:20 local time.

Even though the hunting and killing of a reindeer was not observed directly, it is highly probable. The area was visited by author few days before for counting the reindeer population without observing any injured or ill animals. The population at 
the end of the summer is on its fitness maximum as well, therefore weak individuals suffering from starvation are highly improbable to occur. The place was observed from a tourist boat around 15:00 without noticing the presence of a bear nor carcass. These factors are suggesting active hunt. It is very likely that the hilly terrain also contributed to the successful hunt.

\section{Discussion and Conclusion}

The hunting of a reindeer by polar bear is an exceptional case considering the usual diet and behaviour of a polar bear (Derocher et al. 2002, Iversen et al. 2013). The actual hunting was not observed, however it is very likely, that the reindeer was put to death, as no carcass was observed at the site in previous days. The environmental conditions in the area near Skansbukta are rather favourable for reindeer population (94 individuals in 2017 and 101 in 2018 respectively) as showed in Kavan et Anděrová (in rev.). Change in hunting strategy and diet composition is likely affected by climatic factors (Amstrup et al. 2006) and consequently by change in composition and abundancy of local seal population the usual polar bear prey (Derocher et al. 2002). In case of Billefjorden area, the local seal population (both bearded and ringed seals) is concentrated to Adolfbukta with adjacent tidewater Nordenskiold glacier. Especially bearded seals are connected to this environment and these are closely tight to abundance of icebergs from calving during the summer season and ice floes during the winter season. In recent years, the Nordenskiold glacier experiences transformation from tide water glacier to land based glacier (Kavan et al. in prep.) resulting in diminishing number of icebergs. Considering decrease in availability of natural environment for seal, it is no surprise, that polar bears are changing their diet and hunting strategies. During last years they were feeding on whale carcass as well as on eggs and chicks in the Arctic tern colony directly adjacent to Nordenskiold glacier. An active (although unsuccessful) hunting of a reindeer by polar bear was observed once by the staff of the Adam Mickiewicz University Station in nearby Ebbadalen in August 2012 (Rymer, personal communication). Short distance to the glacier front in habitat selection is especially important for females with young cubs as shown in Freitas et al. (2012), which can explain the high number of them in the area comparing to males, single females or females with older cubs.

An important factor affecting polar bear hunting strategies and dietary changes in recent years is also the growth of the population itself after the complete ban on hunting in 1973 and recovering of the population. Still in 1960ies there were up to 600 polar bears hunted annually, but only several individuals were killed after the ban ([1] - GOS 2017). This resulted in population growth and likely increased habitat pressure. Peacock et al. (2013) identified the population density and worsening of sea ice conditions as main factors influencing the overall polar bear population dynamics in the Davis Strait region (Canada). Similarly, Derocher (2005) found correlation of reproduction and body mass of Svalbard polar bear population with largescale climatic variations, with likely climate change induced trend. Changes in other parameters such as age-structure, reproductive rates and body length show ongoing recovery from 1973 harvest ban and are also likely linked to density-dependent changes in the population (Derocher 2005). The Barents Sea polar bears have experienced the fastest loss of sea-ice habitat of all the 19 recognized subpopulations in the 
Arctic, with an increase in the duration of the summer season. Polar bears in this region will experience a more profound loss of habitat in the next decades compared to most other subpopulations (Aars et al. 2017). An additional pressure is likely to arise with ongoing climatic changes and subsequent rapid decrease in sea ice cover (Amstrup et al. 2010) as an important polar bear habitat. Kovacs et al. (2011) indi- cated danger associated with sea ice cover changes within recent and upcoming decades for most of the Arctic marine mammals. Increased duration that polar bears are likely to spend on land with decreasing sea ice cover (e.g. Stirling et Parkinson 2006, Schliebe et al. 2008) is likely to increase the frequency of reindeer hunting attempts by polar bear (e.g. Gormezano et Rockwell 2013).

\section{References}

Aars, J., Marques, T. A., Buckland, S. T., Andersen, M., Belikov, S., Boltunov, A. and Wiig, Ø. (2009): Estimating the Barents Sea polar bear subpopulation size. Marine Mammal Science, 25: $35-52$.

Aars, J., Marques, T. A., Lone, K., Andersen, M., Wiig, Ø., Bardalen Fløystad, I. M., Hagen, S. B. and BuckLAND, S. T. (2017): The number and distribution of polar bears in the western Barents Sea. Polar Research, 36: 1-16.

Amstrup, S. C., Stirling, I., Smith, T. S., Perham, C. and Thiemann G. W. (2006): Recent observations of intraspecific predation and cannibalism among polar bears in the southern Beaufort Sea. Polar Biology, 29: 997-1002.

Amstrup, S. C., Deweaver, E. T., Douglas, D. C., Marcot, B. G., Durner, G. M., Bitz, C. M. and BAILEY, D. A. (2010): Greenhouse gas mitigation can reduce sea-ice loss and increase polar bear persistence. Nature, 468: 955-958.

BRoOK, R. K., RichARDSON, E. S. (2002): Observations of polar bear predatory behaviour toward caribou. Arctic, 55: 193-196.

Derocher, A. E., Wiig, O. and Bangjord, G. (2000): Predation of Svalbard reindeer by polar bears. Polar Biology, 23: 675-678.

Derocher, A. E., WiIg, O. and ANDERSEn, M. (2002): Diet composition of polar bears in Svalbard and the western Barents Sea. Polar Biology, 25: 448-452.

Derocher, A. E. (2005): Population ecology of polar bears at Svalbard, Norway. Population Ecology, 47: 267-275.

Freitas, C., Kovacs, K.M., Andersen, M., Aars, J., Sandven, S., Skern-Mauritzen, M., PAVlova, O. and Lydersen, C. (2012): Importance of fast ice and glacier fronts for female polar bears and their cubs during spring in Svalbard, Norway. Marine Ecology Progress Series, 447: 289-304.

Gormezano, L.J., Rockwell, R.F. (2013): What to eat now? Shifts in polar bear diet during the ice-free season in western Hudson Bay. Ecology and Evolution, 3: 3509-3523.

Iversen, M., Aars, J., Haug, T., Alsos, I. G., Lydersen, C., Bachmann, L. and Kovacs, K. M. (2013): The diet of polar bears (Ursus maritimus) from Svalbard, Norway, inferred from scat analysis. Polar Biology, 36: 561-571.

Kavan, J., AndĚrovÁ, V. (in review): Environmental factors influencing Svalbard reindeer (Rangifer tarandus platyrhyncus) population characteristics.

KAVAN, J. (in preparation): Retreat rate of Nordenskiold glacier and implications for recent biodiversity - are we witnessing shift from tide water glacier towards land-based glacier?

Kovacs, K. M., Lydersen, C., Overland, J. E. and Moore, S. E. (2011): Impacts of changing sea-ice conditions on Arctic marine mammals. Marine Biodiversity, 41: 181-194.

Peacock, E., Taylor, M. K., LAake, J. and Stirling, I. (2013): Population Ecology of Polar Bears in Davis Strait, Canada and Greenland. The Journal of Wildlife Management, 77: 463476. 
Pedersen, A. (1945): Der Eisbar (Thalarctos maritimus Phipps): Verbreitung und lebensweise. Aktieselskabet Bruun, Copenhagen; in Derocher et al. (2000).

Schliebe, S., Rode, K.D., Gleason, J.S., Wilder, J., Proffitt, K., Evans, T. J. and Mille, S. (2008): Effects of sea ice extent and food availability on spatial and temporal distribution of polar bears during the fall open-water period in the Southern Beaufort Sea. Polar Biology, 31: 999-1010.

Stempniewicz, L., Kidawa, D., BARCikowski, M. and Iliszko, L. (2014): Unusual hunting and feeding behaviour of polar bears on Spitsbergen. Polar Record, 50: 216-219.

StiRling, I., PARKInSON, C. L. (2006): Possible effects of climate warming on selected populations of polar bears (Ursus maritimus) in the Canadian Arctic. Arctic, 59: 261-275.

Tartu, S., Bourgeon, S., Aars, J., Andersen, M., Ehrich, D., Thiemann, G. W., Welker, J. M. and RoutTI, H. (2016): Geographical area and life history traits influence diet in an arctic marine predator. PLOS ONE, 11: 0155980.

TYLER, N. J. C. (1987): Natural limitation of the abundance of the High Arctic Svalbard reindeer. $\mathrm{Ph} . \mathrm{D}$. thesis, University of Cambridge, Cambridge.

WiIG, Ø., AARS. J. and BORN, E. W. (2008): Effects of climate change on polar bears. Science Progress, 91: 151-173.

\section{Web sources / Other sources}

[1] The Governor of Svalbard (GOS) (2017): Number of polar bears killed since 1973. Environmental monitoring of Svalbard and Jan Mayen (MOSJ).

Available at: http://www.mosj.no/en/influence/hunting-trapping/polar-bear-bag.html

[2] United States Geological Survey (USGS) (2018). Available at: https://earthexplorer.usgs.gov/ (accessed November $26^{\text {th }} 2018$ ). 